\title{
Marcel Proust's Lifelong Tour of the Parisian Neurological Intelligentsia: From Brissaud and Dejerine to Sollier and Babinski
}

\author{
Julien Bogousslavsky \\ Department of Neurology, Genolier Swiss Medical Network, Clinique Valmont, Glion-sur-Montreux, Switzerland
}

\section{Key Words}

Aphasia $\cdot$ Emotions $\cdot$ History of neurology • Proust, Marcel • Memory $\cdot$ Psychosomatic disorders $\cdot$ Sollier, Paul

\begin{abstract}
In Search of Lost Time, the main novel of Marcel Proust (18711922) gives prominence to medicine, especially to neurology. Proust possessed excellent medical knowledge and maintained lifelong contact with neurologists. From 1881 onward, he experienced recurrent attacks of asthma, a condition which, at the time, was considered belonging to 'neurasthenia'. Marcel's father, Adrien Proust, was a famous physician who had written papers on stroke, aphasia, hysteria and neurasthenia, and who introduced his son to Charcot's pupil, Edouard Brissaud, the founder of the Revue Neurologique. Three years later, Brissaud published a landmark book on asthma with a preface by Adrien Proust. In 1905, when Proust intended to undergo a 'cure' in order to improve his asthma and other symptoms, he first considered treatment by Jules Dejerine, who was to become Charcot's second successor. He also considered two Swiss physicians who had studied with Charcot and Vulpian: Henry Auguste Widmer, founder of the Clinique Valmont above Montreux, and Paul Dubois, a schoolmate of Dejerine, who practiced in Berne. Brissaud recommended Paul Sollier, under whose care Proust followed a 6-week 'isolation cure'; Sollier, along with Babinski, was considered the cleverest of Charcot's followers. He had
\end{abstract}

studied memory extensively, in particular affective memory, which caused him to reject Bergson's theories and now makes his work a major precursor. Sollier attempted to trigger 'emotional revivals' (reviviscences), 'reproducing the entire state of the personality of the subject at the time of the initial experience'. This concept was integrated by Proust into his novel, with emphasis on 'involuntary memory'. Proust's last neurologist was Joseph Babinski, whom he consulted repeatedly because he feared becoming aphasic, like his mother. Proust's unusual life journey with the most celebrated neurologists of his time highlights aspects of his literary work and also provides a unique perspective on the neurological intelligentsia at the turn of the 19th century.

Copyright $\odot 2007$ S. Karger AG, Basel

The greatest French novelist of the 20th century, Marcel Proust (1871-1922) (fig. 1), is one of the writers for whom disease and medicine assumed a critical place, both in life and in work. Proust suffered from recurrent attacks of asthma from the age of nine, subsequently developing chronic obstructive bronchopneumopathia with superimposed infections, which finally led to his demise at age 51. His father Adrien and his brother Robert were also famous doctors, and at home Proust was immersed in a medical atmosphere, which became a major source of inspiration for his most famous novel, In Search of Lost Time (also poorly translated as Remembrance of Things

\section{KARGER}

Fax +4161306 1234 E-Mail karger@karger.ch www.karger.com
(C) 2007 S. Karger AG, Basel

0014-3022/07/0573-0129\$23.50/0

Accessible online at:

www.karger.com/ene
Julien Bogousslavsky, MD

Department of Neurology

Genolier Swiss Medical Network, Clinique Valmont-Genolier

$\mathrm{CH}-1823$ Glion-sur-Montreux (Switzerland)

Tel. +41 21962 3700, Fax +41 21962 3838, E-Mail jbogousslavsky@valmontgenolier.ch 


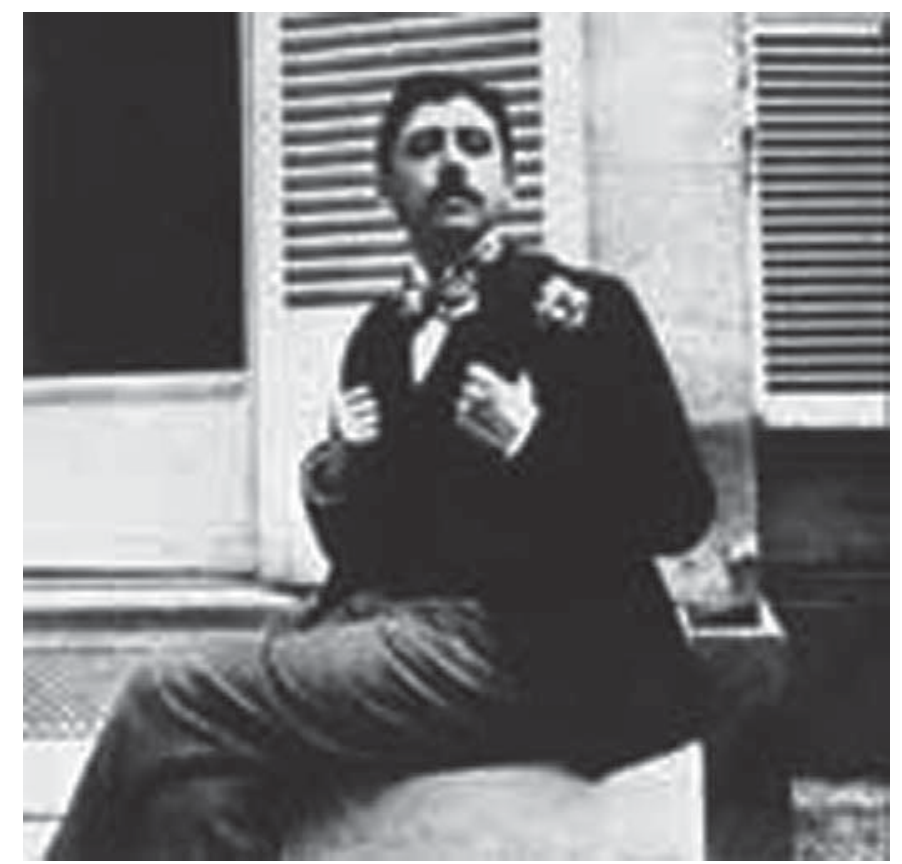

Fig. 1. Marcel Proust (1871-1922).

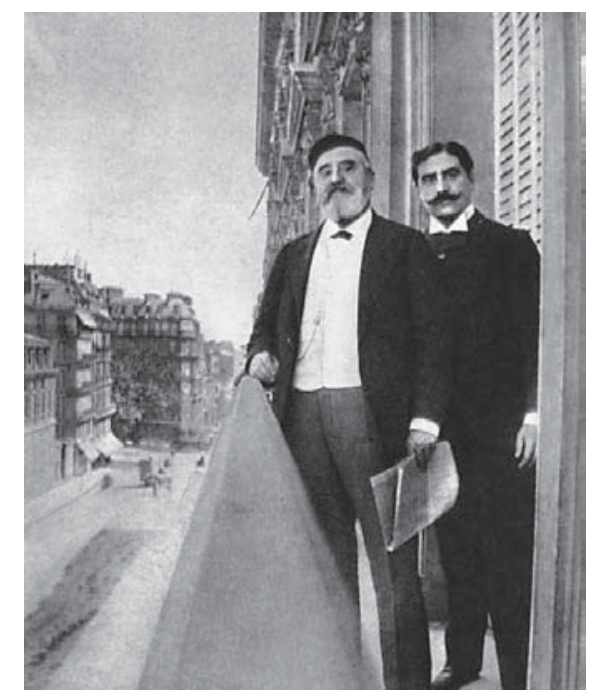

Fig. 2. Marcel Proust's father Adrien and his brother Robert on the family home balcony, rue de Courcelles in Paris.

Past). His contemporaries often observed Proust's identification with doctors, which sometimes inspired him to write medical prescriptions for friends, so that he could say to his faithful housewife Céleste Albaret: 'I am more of a doctor than the doctors' [1].
Far less known is his close relationship with the most famous neurologists of his time, who were the direct successors of Charcot, a man his father had known well during his training and who died when Proust was 12 years old. Indeed, during Proust's time, asthma was considered a 'nervous' disease, which had been classified into a broader condition called 'neurasthenia' in 1880 [2]; today, 'neurasthenia' would cover several psychosomatic disorders. In 1897, Adrien Proust, along with Gilbert Ballet, published The Hygiene of the Neurasthenic [3], one year after writing the preface to The Hygiene of the Asthmatics by Edouard Brissaud [4]. Brissaud was one of Charcot's favourite pupils and, along with Pierre Marie, the founder of La Revue Neurologique in 1893, just a few months before Charcot's death. Apart from Brissaud himself, Proust sought the advice of Jules Dejerine, Vulpian's pupil and second successor to Charcot to the Chair of Diseases of the Nervous System at La Salpêtrière, as well as other famous neurologists, in particular Paul Sollier and Joseph Babinski, who, at the time, were considered the two most gifted pupils of Charcot - even by Charcot himself [5].

\section{The Neurological Background of Marcel's Father, Adrien Proust}

Adrien Proust (1834-1903; fig. 2) enjoyed a successful medical career in Paris, especially for his work on cholera and hygiene. He was elected to the Chair of Hygiene in 1885 and subsequently to the Academy of Medicine. He was the founder of the International Office of Hygiene, the predecessor of the World Health Organization. However, he also made significant contributions to neurology, including his thesis entitled 'On the Different Forms of Brain Softening', which was published in 1862 . He became interested in labio-glosso-pharyngeal palsy and aphasia, on which he published two landmark works in 1872 [6] and 1874 [7].

In 1890, Adrien Proust presented the case of Emile X. to the Academy of Moral Sciences. X. was a young lawyer who showed 'ambulatory automatisms' as part of his hysterical manifestations [8]. He then became more and more interested in neurasthenia, which at the time was also called 'hypochondria', 'nervous exhaustion', 'nervosism' or 'general neuralgia' [9]. In his book, Adrien Proust [3] emphasized the effects of a 'bad education', where the mention of excessive maternal attention and preoccupation clearly points to the relationship between his wife and their son Marcel. While dozens of letters from Marcel to his mother are known, only three to his father have been 
found [10]; but nothing suggests that the father-son relationship was not mutually good and loving, even characterized by a marked identification of Marcel with his father. It is particularly interesting to consider that the 'neurasthenic manifestations' of Marcel Proust were precisely a domain of expertise for his father. Was neurasthenia a subject of discussion during family meals and thus influenced Marcel's symptoms, or did the father become interested in neurasthenia when he realized that Marcel was developing its manifestations? Both factors probably contributed to this particular and specific link between father and son, which subsequently had a major influence on Marcel Proust's novel. Proust's fascination with medicine and doctors markedly increased in 1904/1905, shortly after his father died, when he wrote to the poetess Anna de Noailles that he had decided 'to write a book on doctors' [11].

Thanks to his father, Marcel Proust also met many famous physicians of his time, including Dieulafoy, Pozzi and Vaquez. He also met Cotard, a fellow student of his father, whose name is still associated with the 'syndrome of negations' [12] and to which Proust later added a ' $t$ ', modifying it into Cottard, the most important medical character of his novel. Through his friend, the painter Jacques-Emile Blanche, Proust also met the father, Antoine Blanche, who had cared for the writer Guy de Maupassant when he developed general palsy, and whose own father had cared for the poet Gérard de Nerval before he committed suicide. Proust never met Charcot, who died when Proust was 12 years old, and who had been a young active agrégé when his father had started his internship. However, he later met his son, Jean-Baptiste Charcot, who at first followed his father into neurology before becoming even more famous as a polar explorer. However, the list of all of the physicians whom Proust met will never be complete $[13,14]$. Proust was fascinated by medicine and identified himself with physicians, but with a strong ambivalence, which made him say that the main effect of medicine is to prolong diseases, and that 'to believe in medicine is folly, but not to believe in it is bigger folly yet' [15].

\section{Proust's 'Neurasthenia'}

Proust was considered a weak child but his first manifestation of disease only occurred at the age of nine. During a walk with his parents and Dr. Duplay and his family in the Bois de Boulogne, he developed an asthma attack which his father thought would kill him (fig. 3). Proust's asthma subsequently worsened during adoles-

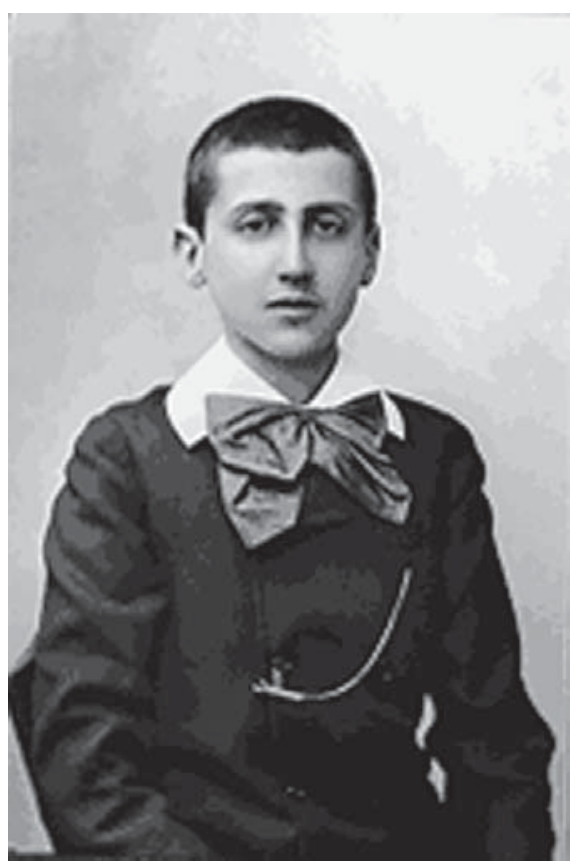

Fig. 3. Proust as a child shortly after he developed asthma.

cence, then remitted slightly (he performed his military service at age 19), before worsening again after age 23 , when it started to influence Proust's lifestyle more and more [16-22]. Over time, Proust also developed chronic obstructive pulmonary disease with an enlarged anterior-posterior chest diameter $[23,24]$ and repeated bronchopulmonary infections, which finally killed him. While asthma was the main, acute manifestation of Proust's disease, the list of his associated problems was long: bad digestion, insomnia, cardiac spasms, headaches, back pain, dizziness, gait imbalance, movement awkwardness, slurred speech, memory loss, thermal dysregulation and 'general weakness', which often kept him bedridden for several days at a time, justifying the diagnosis of 'neurasthenia' [25-27]. In 1904, Dr. Merklen, a chest specialist at Hôpital Laennec, stated to Proust that his asthma had become a 'nervous habit', and recommended that he consult with Dr. Paul Dubois in Berne. At the same period, Proust asked Dr. Léon Faisans, the physician in whom he had the highest degree of confidence, whether he should consult with Jules Dejerine, since his asthma was 'nervous' [27].

As a patient, Proust was famous for his lack of discipline and constant self-administration of drugs, where stimulants and sedatives coexisted, including caffeine, 


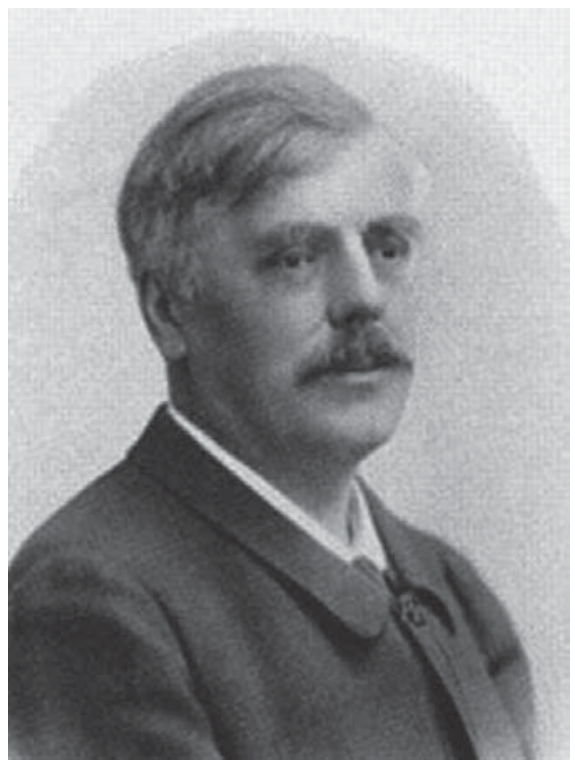

Fig. 4. Edouard Brissaud, co-founder of $\mathrm{La}$ Revue Neurologique, who inspired the character of Dr. du Boulbon in Proust's novel and who recommended Dr. Paul Sollier to Proust for his 'cure'.

sparteine, adrenaline, euvalpine, barbiturates (e.g. trional and veronal), chloral, ether sirup, morphine and others. Anti-asthma cigarettes and pectoral powder fumigations also played a central role [1]. Shortly before he died, Proust was literally living on coffee and cold beer alone, which he had specially delivered from the Ritz in Paris. These mixtures, of course, had side effects, which Proust well recognized, for instance, when he said that chloral was 'making holes' in his brain [27]. His insomnia, which finally led to a complete reversal of his sleep-wake cycle (he was waking up at 8 or 9 p.m. and asked his mother to fix breakfast for him at 11 p.m.), was also greatly worsened by this erratic auto-medication, and episodes of toxic coma occurred at least twice, in 1917 and in 1921 [1]. From 1904 until his death, Proust enjoyed treatment by his faithful general practitioner, Dr. Bize, who had been recommended to him by his brother Robert (who became a famous urologist), and who visited him every Friday, yet complaining of the total lack of compliance by his patient. Proust used to send him flowers to be forgiven.

Proust's attitude toward his disease was as ambivalent as it was toward medicine in general, which is clearly visible in his correspondence. While he wrote to Sidney Schiff that he did not like to complain or to talk about his health, he also commonly expressed the deep pains as- sociated with being chronically ill and the feeling that he would soon die:

During these days, which for me are true agony because of the physical and moral suffering (...) I am about to die and my reply will just be the wish of an agonizing person (...) I am living in bed, dying (...) I am extremely sick, with 800 letters late (...) During all these weeks during which I did not stop dying

(...) I do not know if you know that I have been particularly and awfully dying (...) [11].

It also appears that Proust frequently used his disease to avoid replying to letters and to get rid of visitors, especially at the end of his life, when he had become more famous. Proust was literally living with his disease as a companion, which markedly influenced his work. Quite realistically, he signed one of his books to his cook Céline Cottin as 'the perpetual sick'.

\section{Proust's First Contacts with Neurology}

Proust first heard of neurological diseases from his father who, while still in training, had worked at times under the influence of Charcot, who had conducted studies on stroke, aphasia, hysteria and neurasthenia. These studies were well known to Marcel Proust. However, it is noteworthy that it is only after his father's death in 1903 that Proust's interest in neurology and neurologists increased. This was probably partly due to the cause of his father's death: he was found unconscious on the floor on November 23, and died three days later with a diagnosis of cerebral hemorrhage. When Proust's mother died of a stroke less than two years later (with hemiparesis and aphasia) at the age of 56, his concern over getting a brain disease was reinforced further. Later in his life, he became terrified of developing aphasia, with the need to undergo a 'trepanation', a concern probably rooted in the very title of one of his father's books, Aphasie et Trépanation [7].

Proust met Edouard Brissaud (1852-1909; fig. 4) through his father. Adrien Proust had become acquainted with Brissaud through Charcot and he later wrote the preface to Brissaud's book on The Hygiene of the Asthmatics [4]. Brissaud was one of the founders of La Revue Neurologique in 1893, with the blessing of Charcot, by whom he was considered to be one of his most faithful followers. Marcel Proust, when creating the character of Dr. du Boulbon (a doctor making diagnoses based on immediate intuition) in his novel, was inspired by Brissaud [28] and he wrote: 'A specialist of nervous diseases, the one to whom Charcot, before dying, had predicted that he would reign 
in neurology and psychiatry' [9]. Brissaud, indeed, was an uncommon physician, known for his 'famous jokes' and considered 'a sentimental, Romanesque person', someone who 'liked to laugh' and 'to mystify' [5]. Proust's friend, Léon Daudet, who began his medical career under Charcot (Charcot was a great friend of his father, Alphonse Daudet), stated that Brissaud never really fulfilled the hopes that many had placed in him, because he 'never completely escaped from Charcot's influence (sterilizing from a therapeutic point of view)' [5]. Proust called Brissaud 'a doctor despite himself', since it was so difficult to make him speak of medicine, like Dr. du Boulbon in the novel. He also alluded to his simplistic attitude to treatments: 'An admirable man, with vast intelligence, but a poor physician, who thought (...) that one should live on trional' [11]. In his work on asthmatics, well known to Proust, Brissaud underlines their 'premorbid, capricious and autocratic personality', corresponding to a 'pure neurosis' [4].

In 1904/1905, with the encouragement of his mother, Proust considered the possibility of being admitted to hospital for 'a cure', an idea which was reinforced by the mother of his friend Jacques Bizet, Madame Straus. Madame Straus suffered from neurasthenia and was a patient of Dr. Henry Auguste Widmer (1853-1939), who had just opened the Clinique Valmont in Glion-surMontreux, overlooking Lake Geneva in Switzerland. Dr. Widmer was a contemporary of Brissaud, who had also studied with Charcot in Paris before specializing in digestive disorders, diet and nervous dysfunction. The Clinique Valmont thus became the first sanatorium in Switzerland to deal with conditions other than tuberculosis and mental illness. Madame Straus went to Valmont several times and she also advised Proust to consult Dr. Widmer. In September 1905 Proust went to Evian on Lake Geneva with his mother, planning to see either Dr. Widmer in Valmont or Dr. Paul Dubois (18481918), a neuropsychiatrist established in Berne. Dubois had been to school with Jules Dejerine at the Collège Calvin in Geneva. Dubois' friends Anna de Noailles and Fernand Gregh had consulted Dejerine. Dubois' book The Psychoneuroses and Their Moral Treatment [29], which included a preface by Dejerine, was well known to Proust. However, the first manifestations of the stroke that would kill Proust's mother a few days later developed just before Proust could see Widmer or Dubois, interrupting his stay in Evian. His mother's death was the event that made Proust decide to go into a sanatorium for a 'cure', which is what his mother so much wanted him to do [25-27].

Proust and the Parisian Neurological Intelligentsia

\section{The Many Misunderstandings of Proust's Treatment at Paul Sollier's Clinic}

The death of his mother was a terrible shock to Proust. He thought he would not be able to overcome his loss, and it also meant a great change in his habits, since he had been living with her since his birth. Several years later, he said: 'When dying, Mom took with her the little Marcel' [1]. Proust envisioned staying at a sanatorium for some time, and initially thought of being under the care of Jules Dejerine (1849-1917), who would become Charcot's second successor six years later at the Chair of the 'Clinique des Maladies du Système Nerveux' in La Salpêtrière. Dejerine had written the preface to Dubois' book [29] and also to Isolation and Psychotherapy. Treatment of Hysteria and Neurasthenia by Camus and Pagniez [30], which emphasized strict isolation from the patient's usual world as the central principle of therapy. Proust reserved a room for December 5, 1905, at Dejerine's 'Clinique des Soeurs de la Sainte-Famille' in the rue Blomet in Paris (the building still exists today). However, as the date approached he became more and more anxious because Dejerine's cure included a strict 3-month isolation. Still thinking of Widmer or Dubois in Switzerland, he consulted Brissaud, who recommended Dr. Paul Sollier (1861-1938).

Sollier's name has largely been forgotten today, probably because he was mainly interested in areas common to both neurology and psychiatry, so that, later on, he was considered neither a neurologist nor a psychiatrist. He had worked with Bourneville and was the first to introduce a quantification of intellectual performance in idiots, which subsequently led to the development of the concept of 'intellectual coefficient'. He was indeed one of the very brightest neurologists of his time, so that Léon Daudet, who was usually very critical, considered Sollier and Babinski the best followers of Charcot and the cleverest collaborators during the rounds: 'Those two are the most acute and best observers, they will be mastering the famous syndrome of hysteria, the theory of memory, the technique of demorphinization, anorexia nervosa, tabes peripheral neuritis, etc.' [5]. On December 4, Proust cancelled his room reservation at Dejerine's clinic and arranged an appointment with Sollier, who convinced him to come to his clinic in Boulogne-sur-Seine (which later became the hospital Ambroise Paré, before it was destroyed during World War II by allied bombing of the nearby Renault factory) on December 6. It is likely that the main reason for Proust's acceptance was that Sollier's isolation cure lasted only six weeks. Besides, Léon Daudet had also told Proust about Sollier's interest in homosexu- 
ality [9], although one does not know whether this topic critical to Proust was ever discussed during his stay with Sollier. While Proust never stated the exact reasons for his decision to undergo a 'cure' with Sollier, the principle objectives probably included respect for his mother's wish, the improvement of his asthma, a deep self-exploration in order to retrieve a 'will' for artistic creativity, which he thought he was losing [9], and the re-equilibration of his desynchronized sleep-wakefulness cycle.

Isolation as the centre point of the cure had been well detailed in Camus and Pagniez' [30] book, which Proust had read. It was not totally new, since Esquirol had already proposed it in 1838 , before being followed by Charcot [9]. In principle, the patient was not allowed to communicate with anyone except his doctor and specific surveillance staff, who decided whether nurses could also communicate or not. The patient had to stay in bed for at least one week and live exclusively on a milk-based diet in order for him to 'regress' and become more and more 'dependent' upon his doctor. However, Sollier's cure was known to be less strict, and Proust was soon allowed to dictate, then write, letters to friends, whom he could even receive for two hours three afternoons a week for the last three weeks of his stay [26].

Sollier was an expert on hysteria and memory, having written several books on the subject [31-33]. His memorybased therapeutic approach was innovative and makes him a forgotten precursor to several better-known neuropsychiatrists, including Sigmund Freud, who had probably met him during his stay in Paris with Charcot. Sollier attempted to have his patients experience 'emotional revivals' (reviviscences), which, contrary to voluntary memories, permitted reactivating an entire emotional state:

\footnotetext{
A memory is an image (...) which reproduces a past impression. An emotional revival is much more: it is not only the appearance in the field of consciousness of a past image or impression, but very clear and with the precise and intense reproduction of the entire state of the personality of the subject at the time of the initial experience, so that the patient feels as if he is again going through the same events as before [32].
}

Sollier tried to obtain such a 'catharsis' through sensory stimulations and awareness of inner and outer stimuli during his meetings with his patients.

It is striking that Sollier's theory is nearly identical to Proust's subsequent analysis of what he called involuntary memory', the outbursts of which led to the narrator's vocation to become a writer in In Search of Lost Time [15], underlining the influence of Sollier on Proust, which has been greatly overlooked. Indeed, the classic biographies of Proust systematically omit quoting Sollier's method and ideas, ignoring him as an acclaimed physician and denying him any therapeutic skills. In fact, Proust himself may be partly responsible for this attitude, having remained totally silent on his therapy with Sollier, even in the thousands of pages of his correspondence. Moreover, a quote from Proust about his cousin, the famous philosopher Henri Bergson, to his friend de Lauris two years later has been systematically misinterpreted [9]:

I remember that one of the first topics Sollier and I talked about when I entered his sanatorium was Bergson, whom he had to read because he thinks that his domain is the same: 'What a confused and narrow mind!' I felt a da Vinci-like smile of intellectual superiority pass on my face. And this did not add to the success of the psychotherapeutic treatment.

This quotation has been interpreted as reflecting Sollier's poor knowledge of Bergson's ideas, in particular his theory of time and memory. However, Sollier's sophisticated books on memory published several years before Proust's cure demonstrate that he knew Bergson's theories in great detail $[31,32]$. In fact, he strongly disagreed with them, emphasizing Bergson's unwarranted 'spiritualism', his lack of emotional components in memories, and his poor knowledge of neuro-anatomical correlations [32]. It is thus not unlikely that Proust, who knew Bergson personally but ignored that Sollier had studied - and criticized - his memory theory so well, fell into the trap of discussing this with Sollier, who might have been giving him a lesson! This quarrel between Proust and Sollier seems particularly paradoxical, since Sollier was underlining the role of 'emotional revivals', which are totally absent in Bergson's writings but which constitute the basis of 'involuntary memory' in Proust's novel. Moreover, in 1913, Proust made it very clear that he had not written a Bergsonian novel, since the philosopher did not make any distinction between voluntary and involuntary memory [27]. On the other hand, he put forward a distinction between a simple memory and an 'emotional revival', which was indeed the basis of Sollier's concept!

The poor consideration Proust experts have given to Sollier has been associated with statements by Proust himself, who wrote to friends that his cure was doing him harm $[26,27]$. However, in French the word for harm also means pain, and Proust may have suggested that his treatment was painful. It is obvious that Proust was very ambivalent about a hospital stay anywhere and that it had mainly been triggered by the death of his mother. A sixweek stay in hospital was obviously unlikely to modify Proust's asthma. On the other hand, the treatment was very helpful in reorganizing Proust's disturbed sleep- 
wakefulness cycle. Moreover, if one considers that, for Proust, a major goal was to retrieve his 'will' to become a writer, the cure at the hands of Sollier can certainly be seen as a success. Besides, it also appears that several of Proust's ideas on emotional remembering go back to his interaction with Sollier, whose theory of memory Proust largely integrated in his novel.

Proust twice sent his novel's narrator to a sanatorium [15], but never repeated his own cure experience, despite consultations with Dr. Widmer in Valmont during the years 1911-1913. It is interesting that, in his more than 3,500-page novel, Proust remained as silent on the narrator's cures (although he mentioned that they lasted for years) as he had been on his own stay with Dr. Sollier.

Despite his prophetic work on emotional memory and his famous patient, Sollier has also been forgotten by the historians of neurology, and his name cannot even be found in the classic books on the history of neurology [34-36]. He is quoted only once or not all in the main reference books on Charcot and his school [37,38]. He is also absent from current textbooks on neuropsychology and memory, but clearly deserves to be rehabilitated as a pioneer in cognition and emotion.

\section{Proust and Babinski: The Painful End of a Life of Pains}

'Proust seems to know all the neurologists in Europe', emphasized the Proust expert Tadié [27]. In Paris, Proust met Pierre Marie's pupil, Nicolas Vaschide, who became a specialist on sleep and dreams, and shortly before his death he recommended Dejerine's favourite pupil, Gustave Roussy, to his publisher [39]. However, the main neurological contact of Proust during the last years of his life was Joseph Babinski (1857-1932). Babinski, along with Dejerine, was considered the finest clinical neurologist of his time, although he was never given a chair at the faculty. 'Without doubt the first neurologist in the universe', wrote Léon Daudet, who had worked with him at the time of Charcot [5], while Proust referred to him in his novel when mentioning 'a celebrity of nervous diseases' [15]. Proust knew Babinski because Babinski had cared for his mother when she had become aphasic in 1905, yet he consulted with him only in 1918 when, beside his endlessly recurrent asthma attacks, he feared following the same fate as his mother, developing facial palsy with the need for a trepanation [26, 27]. Babinski quickly reassured him, but Proust consulted with him again the following year for 'slurred speech', which he feared was concealing

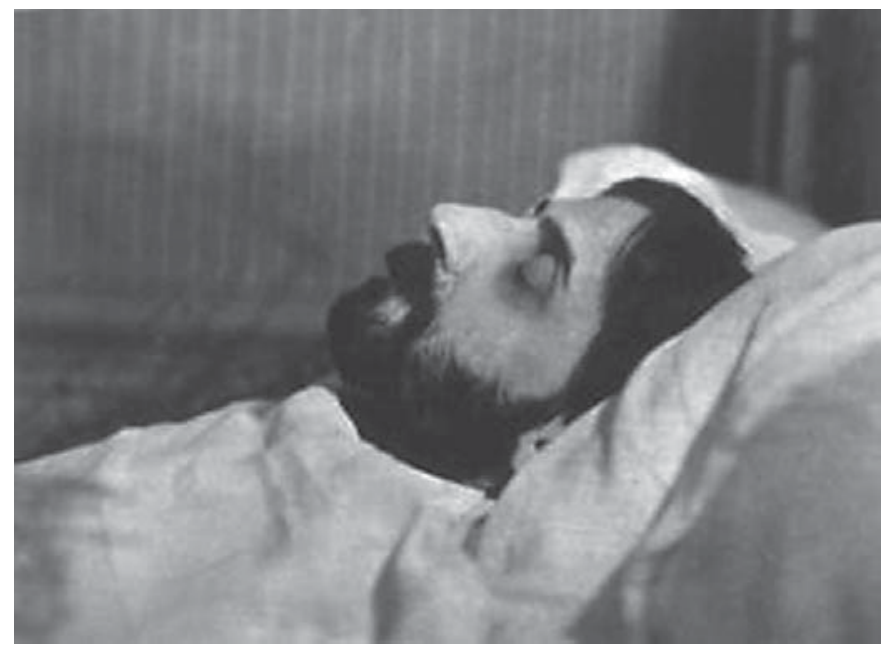

Fig. 5. Proust on his death bed, November 18, 1922, a few hours after Babinski left him.

a 'grave cerebral cause', although he also admitted that veronal abuse could be responsible. Proust reported that Babinski had him repeat unusual and complicated words in order to reassure him again. Nevertheless, at that time Proust wrote that 'a foreign lady has taken domicile in my brain', something which made him identify himself with Baudelaire, who had died aphasic. In the midst of Proust's somewhat irrational fears, one can also observe his perfect clinical sense; he wrote that he could easily exclude syphilitic general paresis: 'I know that this cannot be the beginning of general paresis, since all my reflexes are excellent and I never had a venereal disease' [11]. In fact, Proust's last manifestations of slurred speech, dizziness, blurred vision, loss of balance, awkwardness and forgetfulness can mainly be attributed to his chronic abuse of various medications, which may also have been responsible for visual hallucinations ('a fat lady in black') [28, 39]. However, he never lost the fear that these were premonitory symptoms of a stroke, which he even introduced with Bergotte's death in the last part of In Search of Lost Time [15].

Proust did not die of a stroke but of a complicated bronchopneumonia, which he refused to treat, despite the pleas of his general practitioner (Dr. Bize) and his brother Robert. On November 18, 1922, while Proust was suffocating, they called Babinski, who could only report that 'it is all over', and who suggested stopping any treatment. Proust died shortly thereafter, during a painful agony, at age 51 [1] (fig. 5).

Eur Neurol 2007;57:129-136 
Proust's complaint of forgetfulness and 'poor memory' with difficulty remembering what he wanted to remember (voluntary memory) should be put into the perspective of his emphasis of involuntary memory, since this type of memory may be triggered by an impairment of attention and concentration [40]. In a letter to Léon Pierre-Quint in 1925, Jacques-Emile Blanche [41] remembered that Proust 'was suffering from memory disorders (...) but he was playing with them'. Involuntary outbursts of certain memories associated with a strong affective component could indeed have been facilitated by Proust's voluntary memory dysfunction, as he emphasized himself in his novel: 'The intermittences of the heart are associated with memory troubles' [15]. Interestingly enough, Proust's father had already alluded to the 'complex play of emotional states (...) in awake sleepers' several years before, in his book The Hygiene of the Neurasthenic [3]. It made him conclude that 'the evocation of memories is defective because they [the neurasthenics] are unable to sustain the effort of attention necessary for the search of lost memory.' It is fascinating that, with these last five words, Adrien Proust had almost named the title of the famous novel which his son would start to write over ten years later.

\section{Acknowledgement}

I thank Mark Inglin for his thorough editing services. The figures first appeared in P. Abraham: Proust. Paris, Les Editions Rieder, 1930, except fig. 4 (private collection).

\section{References}

1 Albaret C: Monsieur Proust. Paris, Robert Laffont, 1973.

2 Beard GM: A practical treatise on nervous exhaustion neurasthenia. New York, 1880.

3 Proust A, Ballet G: L'hygiène du neurasthénique. Paris, Masson, 1897.

4 Brissaud E: L'hygiène des asthmatiques. Paris, Masson, 1896.

5 Daudet L: Souvenirs et polémiques. Paris, Laffont, 1992.

6 Proust A: De l'aphasie. Paris, Asselin, 1872.

7 Proust A: Aphasie et trépanation. Paris, Masson, 1874.

8 Proust A: Cas curieux d'automatisme ambulatoire chez un hystérique. Trib Méd 1890;13: 202-203.

9 Bizub E: Proust et le moi divisé. La Recherche: creuset de la psychologie expérimentale (1874-1914). Geneva, Droz, 2006.

10 Tadié J-Y (ed): Marcel Proust, l'écriture et les arts. Bibliothèque Nationale de France/ Réunion des Musées Nationaux. Paris, Gallimard, 1999.

11 Proust M: Correspondance générale. Paris, Plon, 1970-1993.

12 Cotard J: Le délire de négation. Arch Neurol 1882;4:152-170 and 282-296.

13 Seidmann E: Marcel Proust et les médecins. Bull Soc Amis Marcel Proust Amis Combray 1961;12:522-541.

14 Billières R: Les médecins et Marcel Proust. Bull Soc Amis Marcel Proust Amis Combray 1961;12:542-544.
15 Proust M: A la recherche du temps perdu. Bibliothèque de la Pléiade. Paris, Gallimard, 1987-1989.

16 Soupault R: Marcel Proust, du côté de la médecine. Paris, Plon, 1967.

17 Straus B: The Maladies of Marcel Proust: Doctors and Diseases in his Life and Work. New York, Holmes \& Meier, 1980.

18 Falliers CJ: The literary genius and the many maladies of Marcel Proust. J Asthma 1986; 23:157-164.

19 Péquignot $\mathrm{H}$ : La médecine et les médecins dans l'oeuvre de Marcel Proust. Sem Hôp Paris 1988;64:1263-1268.

20 Soupault R: Marcel Proust et les médecins. Lyon Méd 1971;225:1109-1116.

21 Michel FB: Marcel Proust. Pathographie Méd Hyg 1987;45:786-794.

22 Rivane G: Influence de l'asthme sur l'oeuvre de Marcel Proust. Paris, Nouvelle Edition, 1945.

23 Ferrière A: Marcel Proust et l'asthme. Rev Méd Liège 1967;22:287-291.

24 Sharma OP: Marcel Proust (1871-1922): reassessment of his asthma and other maladies. Eur Respir J 2000;15:958-960.

25 Béhar S: L'univers médical de Marcel Proust. Cahiers Marcel Proust, NRF. Paris, Gallimard, 1970.

26 Painter GD: Marcel Proust. Paris, Mercure de France, 1979.

27 Tadié J-Y: Marcel Proust. Biographies NRF. Paris, Gallimard, 1996.
28 Yoshida J: La maladie nerveuse chez Proust: genèse du portrait du docteur du Boulbon. Bull Marcel Proust 1992;42:43-62.

29 Dubois P: Les psychonévroses et leur traitement moral. Paris, Masson, 1904.

30 Camus J, Pagniez P: Isolement et psychothérapie. Traitement de l'hystérie et de la neurasthénie. Paris, Félix Alcan, 1904.

31 Sollier P: Les troubles de la mémoire. Paris, Rueff, 1892.

32 Sollier P: Le problème de la mémoire. Essai de psycho-mécanique. Paris, Alcan, 1900.

33 Sollier P: L'hystérie et son traitement. Paris, Alcan, 1901.

34 McHenry LC: Garrison's History of Neurology. Springfield, Charles C. Thomas, 1969.

35 Haymaker W, Schiller F: The Founders of Neurology. Springfield, Charles C. Thomas, 1970.

36 Riese W: A History of Neurology. New York, MD Publications, 1959.

37 Goetz C, Bonduelle M, Gelfand T: Charcot. Constructing Neurology. New York, Oxford University Press, 1995.

38 Gasser J: Aux origines du cerveau moderne. Localisations, langage et mémoire dans l'œuvre de Charcot. Paris, Fayard, 1995.

39 Mabin D: Le sommeil de Marcel Proust. Paris, PUF écrivains, 1992.

40 Dieguez S: Proust ou la mémoire involontaire. Cerveau Psycho 2006;14:86-90.

41 Collet G-P: Jacques-Emile Blanche. Le peintre-écrivain. Paris, Bartillat, 2006. 